\title{
Ekstrak Tempe Kedelai Hitam dan Ubi Jalar Ungu Terhadap Toleransi Darah Tikus Model DMT2
}

\author{
MUSTIKA AYU WULANSARI ${ }^{1}$, SRI RAHAYU LESTARI ${ }^{2}$, ABDUL GOFUR $^{2}$ \\ ${ }^{1}$ Pendidikan Biologi, Fakultas Matematika dan Ilmu Pengetahuan Alam, Universitas Negeri Malang \\ Jl. Semarang No.5 Sumbersari, Lowokwaru, Malang, Jawa Timur. 65145 \\ ${ }^{2}$ Jurusan Biologi, Fakultas Matematika dan Ilmu Pengetahuan Alam, Universitas Negeri Malang \\ Jl. Semarang No.5, Sumbersari, Lowokwaru, Malang, Jawa Timur. 65145 \\ Email: srirahayulestari@um.ac.id
}

Received 31 January 2018; Received in revised form 5 February 2018;

Accepted 12 March 2018; Available online 9 May 2018

\begin{abstract}
Diabetes mellitus type 2 (DMT2) is caused by the ineffective use of insulin by the body. DMT2 with hyperglycemia causes circulatory system disorders, such as intracellular ion imbalance that causing changes in cell size and cell membrane fragility. Soybean black tempe and purple sweet potato have a potential therapy for patients with DMT2. This study aims to determine the blood osmotic tolerance of rat model DMT2 treated by the mixture of black soybean tempe extract and purple sweet potato. Osmotic tolerance is indicated by the level of erythrocyte membranes damage, i.e. crenation and hemolysis. The results showed that chemical compounds such as glibenclamide works better to lowers damaging of the cell membrane as compared to treatment of a mixture of natural compounds soybean black tempe and purple sweet potato.
\end{abstract}

Keywords: black soybean tempe, DMT2, osmotic tolerance, purple sweet potato

\section{INTISARI}

Diabetes mellitus tipe 2 (DMT2) disebabkan oleh penggunaan insulin yang kurang efektif oleh tubuh. DMT2 dengan hiperglikemia menyebabkan gangguan sistem sirkulasi yaitu terganggunya keseimbangan ion intraseluler sehingga menyebabkan perubahan ukuran sel dan kerapuhan membran sel. Tempe kedelai hitam dan ubi jalar ungu memiliki potensi terapi bagi penderita DMT2. Penelitian ini bertujuan mengetahui toleransi osmotik darah tikus model DMT2 yang diberikan perlakuan campuran ekstrak tempe kedelai hitam dan ubi jalar ungu. Toleransi osmotik ditunjukkan dengan tingkat kerusakan membran eritrosit yaitu krenasi dan hemolisis. Hasil penelitian menunjukkan bahwa pemberian senyawa kimia berupa glibenklamid bekerja lebih baik menurunkan kerusakan membran sel dibandingkan dengan pemberian senyawa alami campuran ekstrak tempe kedelai hitam dan ubi jalar ungu.

Kata kunci: DMT2, tempe kedelai hitam, toleransi osmotik, ubi jalar ungu

\section{PENDAHULUAN}

Diabetes mellitus (DM) adalah salah satu penyakit metabolik yang ditandai dengan kondisi hiperglikemia kronis, akibat kelainan sekresi insulin, kelainan kerja insulin, ataupun keduanya (Ozougwu et al., 2013; Wu et al., 2014). World Health Organization menyatakan jumlah penderita DM di Indonesia akan mengalami kenaikan sebesar 12,9 juta dalam kurun waktu 30 tahun (2000-2030) dan mengalami peningkatan 2-3 kali lipat pada tahun 2035. Hal ini seiring dengan biaya perawatan penderita DM yang juga berkembang sangat tinggi (Arjadi dan Mustofa, 2017).

Terdapat dua kategori utama diabetes mellitus yaitu diabetes mellitus tipe 1 dan tipe 2. Diabetes mellitus tipe 1 disebut insulindependent, ditandai dengan kurangnya produksi insulin. Diabetes mellitus tipe 2 
disebut non-insulin dependent, disebabkan penggunaan insulin yang kurang efektif oleh tubuh (American Diabetes Association, 2014). Penyebab lain perkembangan penyakit DMT2 adalah gaya hidup serba cepat, kurangnya aktivitas fisik, merokok, konsumsi alkohol, makanan, serta faktor genetik (Wu et al., 2014; Betteng dkk., 2014; Prabhu, 2013).

DMT2 dengan gejala hiperglikemia meliputi jumlah urin yang dikeluarkan lebih banyak (poluiria), sering atau cepat merasa haus/dahaga (polidipsia), lapar yang berlebihan atau makan banyak (polyphagia), kehilangan berat badan yang tidak jelas sebabnya dan penglihatan kabur, melambatnya pertumbuhan dan kerentanan terhadap infeksi tertentu juga dapat menyertai penderita hiperglikemia kronik (Hakim dkk., 2009). Diabetes mellitus dapat menyebabkan komplikasi klinis, termasuk anemia, hipoksia dan kerusakan organ (terutama otak, jantung, ginjal, saraf, pembuluh darah dan jantung) (Johnson et al., 2008).

Hiperglikemia menyebabkan gangguan keseimbangan ion intraseluler sehingga menyebabkan perubahan ukuran sel dan kerapuhan membran sel dan berakibat pada gangguan sirkulasi pada diabetes mellitus (Singh and Shin, 2009). Lippi et al. (2012) menjelaskan bahwa hiperglikemia kronik meningkatkan kerapuhan membran sel dengan mengubah sifat membran. Membran eritrosit bersifat permeabel selektif yang dapat ditembus oleh air dan zat-zat tertentu, tetapi tidak dapat ditembus oleh zat-zat tertentu yang lain. Kerusakan membran eritrosit dapat disebabkan oleh penambahan larutan hipotonis/hipertonis ke dalam darah, masuknya zat/unsur kimia tertentu, umur sel yang tua, pemanasan atau pendinginan, tekanan osmotik yang ditentukan oleh konsentrasi zat terlarut dari kompartemen (Silverthorn, 2002). Kung et al. (2009) menambahkan toleransi osmotik pada penderita DMT2 lebih rendah dibandingkan dengan bukan penderita DMT2 akibat adanya hemoglobin glikosilasi. Hemoglobin glikosilasi membatasi pengiriman glukosa, insulin dan oksigen ke jaringan aktif secara metabolik (Tamariz et al., 2008). Hemoglobin glikosilasi menyebabkan salah satu gangguan fisiologi pada sistem sirkulasi darah.

Bahan makanan dengan indeks glikemia rendah dibutuhkan bagi penderita DMT2 untuk membantu mencukupi kebutuhan gizi serta mengontrol kadar glukosa darah. Makanan indeks glikemia rendah tidak menimbulkan peningkatan glukosa darah secara cepat sehingga mampu memperbaiki sensitivitas insulin, meningkatkan dan memperbaiki pembakaran glukosa di jaringan perifer dan memperbaiki sel $\beta$ pankreas serta bermanfaat dalam pengendalian glukosa darah penderita DMT2 (Franz et al., 2014; Rimbawan dan Siagian, 2004).

Antioksidan memiliki potensi terapi bagi penderita diabetes dengan cara melindungi sel dari radikal bebas yang dihasilkan proses glikasi dan transport elektron (Ahmed, 2005). Alternatif sumber antioksidan yang memiliki potensi besar adalah bahan tumbuhan. Beberapa tumbuhan yang diketahui memiliki indeks glikemik rendah dan aktivitas antioksidan tinggi adalah kedelai hitam (Glycine max (L.) Merril) dan ubi jalar ungu (Ipomoea batatas L.) (Cheng et al., 2011; Montilla et al., 2011).

Kombinasi ubi jalar ungu dan kedelai hitam diharapkan mampu menangkal dan mencegah kerusakan membran sel sehingga toleransi osmotik dapat dinormalkan. Berdasarkan hal tersebut, penelitian ini bertujuan untuk mengetahui pengaruh pemberian campuran ekstrak tempe kedelai hitam dan ubi jalar ungu terhadap toleransi osmotik tikus model DMT2.

\section{METODE}

Penelitian berupa penelitian deskriptif eksploratif yang telah mendapatkan persetujuan dari komite etik lokal Indonesia dengan no: 878-KEP-UB.

Pembuatan High Fat Diet (HFD). Komposisi HFD untuk satu resep adalah pakan Hi Go 551 yang dihaluskan (300 g), jagung giling (200 g), minyak jelantah (150 g), yolk telur bebek (100 g), tepung terigu $(50 \mathrm{~g})$, dan asam kolat $(0,1 \mathrm{~g})$. Semua bahan dicampur secara merata selanjutnya ditimbang seberat $20 \mathrm{~g}$. 
Pembuatan Minuman Sukrosa 10\%. Menimbang sebanyak $10 \mathrm{~g}$ gula pasir, ditambah air hingga volume total $100 \mathrm{ml}$ dan dilarutkan hingga homogen.

Pembuatan Tepung Ubi Jalar Ungu. Ubi jalar ungu dibersihkan, dipotong dengan ketebalan 0,3-0,4 cm, dimasukkan ke dalam oven pada suhu $40-50^{\circ} \mathrm{C}$ selama 3-4 hari. Setelah ubi jalar ungu kering dilakukan penggilingan hingga menjadi tepung. Proses penepungan ubi jalar ungu dilakukan di UPT Materia Medika, Batu.

Pembuatan Tepung Tempe Kedelai Hitam. Kedelai hitam yang sudah dicuci bersih kemudian direndam dalam air selama 12-18 jam. Kedelai hitam dilepaskan dari kulit arinya kemudian dicuci dan dibilas menggunakan air bersih. Proses selanjutnya kedelai hitam direbus sampai biji menjadi lunak/empuk, diangin-anginkan hingga bijibiji tersebut terasa hangat. Ragi tempe ditaburkan sedikit demi sedikit sambil diadukaduk supaya merata (1,5 g ragi tempe untuk 2 $\mathrm{kg}$ kedelai). Kedelai hitam dibungkus dengan plastik dengan ketebalan 1-2 cm dan disimpan pada suhu kamar selama satu atau dua hari atau hingga seluruh permukaan kacang kedelai tertutupi jamur. Setelah tempe jadi, diiris tipis dan dikeringkan dalam inkubator bersuhu $60^{\circ} \mathrm{C}$ hingga kering, selanjutnya tempe digiling hingga menjadi tepung halus. Proses penepungan tempe kedelai hitam dilakukan di UPT Materia Medika, Batu.

Ekstraksi Tepung Tempe Kedelai Hitam dan Ubi Jalar Ungu. Sebanyak $10 \mathrm{~g}$ tepung tempe kedelai hitam dan ubi jalar ungu ditimbang dan dilarutkan dalam akuades hingga $100 \mathrm{ml}$, larutan distirer selama 30 menit kemudian dimasukkan dalam tabung sentrifus. Larutan disentrifugasi pada kecepatan 3000 rpm selama 15 menit. Supernatan diambil menggunakan mikropipet dan disimpan dalam botol kaca gelap dalam almari pendingin.

Pembuatan Campuran Ekstrak Tempe Kedelai Hitam dan Ubi Jalar Ungu. Pembuatan campuran ekstrak perlakuan menggunakan sistem perbandingan sama.
Untuk membuat kombinasi ekstrak tempe kedelai hitam dan ubi jalar ungu dengan perbandingan 1:1 (campuran $10 \mathrm{ml}$ ekstrak tempe kedelai hitam dan $10 \mathrm{ml}$ ekstrak ubi jalar ungu).

Pembuatan Obat Hipoglikemik Oral (OHO). Sediaan obat hipoglikemik mengandung $5 \mathrm{mg}$ glibenclamide dalam 100 mg tablet (dosis manusia). Dosis tersebut dikonversi menjadi dosis untuk tikus dengan berat rerata tikus $(180 \mathrm{~g})$ yaitu $0,081 \mathrm{mg} / 180 \mathrm{~g}$. Perhitungan berat obat $\mathrm{OHO}$ yang diperlukan adalah sebesar 1,62 mg dilarutkan dalam 1,5 ml DMSO 25\%.

Pembuatan dan pemilihan Tikus Model DMT2. Hewan coba diaklimatisasi selama satu minggu dan diletakkan di dalam kandang plastik dengan pemberian pakan susu pelet A. Pemberian air minum secara ad libitum. Tikus jantan ( $R$. novergicus) dibagi ke dalam kelompok normal, kontrol dan perlakuan. Kelompok normal diberi pakan susu pelet A dan air minum biasa, sedangkan kelompok kontrol dan perlakuan diberi pakan high fat diet (HFD) dan minuman sukrosa $10 \%$ selama 5 minggu. Setelah 5 minggu perlakuan pakan $H F D$, tikus di injeksi streptozotocin dosis rendah $(30 \mathrm{mg} / \mathrm{kg}$ berat badan dalam 0,1 citrate-buffered saline 4,5) seminggu 2 kali secara intraperitonial (IP). Pengukuran kadar glukosa darah dilakukan dengan cara mengambil darah pada ujung ekor yang dipotong dan darah diteteskan pada ujung alat strip Blood Glucose Test Meter merk On Call EZ dan ditunggu 10 detik sehingga terbaca dengan satuan mg/dl. Kadar glukosa darah diperiksa sebelum dan sesudah penginjeksian streptozotocin. Tikus dikatakan mengalami diabetes mellitus apabila kadar glukosa puasa darah tikus melebihi $200 \mathrm{mg} / \mathrm{dl}$.

Perlakuan Pemberian Kedelai Hitam dan Ubi Jalar Ungu. Hewan coba untuk kelompok perlakuan dengan kadar glukosa darah > $200 \mathrm{mg} / \mathrm{dl}$ selanjutnya dimasukkan ke kelompok perlakuan. Hewan coba dikelompokkan dengan rincian dapat dilihat pada Tabel 1. 
Tabel 1. Kelompok hewan coba yang akan diujikan dengan perlakuan yang ditetapkan

\begin{tabular}{cclc}
\hline No. & Kode Kelompok & \multicolumn{1}{c}{ Jenis Perlakuan } & Jumlah \\
\hline 1. & $\mathrm{N}$ & $\begin{array}{l}\text { Kontrol Normal, diberi pakan standar tanpa } \\
\text { perlakuan }\end{array}$ & 3 \\
\hline 2. & K+ & $\begin{array}{l}\text { Kontrol Positif DM (diinduksi DM), tanpa perlakuan } \\
\text { lanjutan }\end{array}$ & 3 \\
\hline 3. & K- & $\begin{array}{l}\text { Kontrol Obat, diinduksi DM kemudian diberi obat } \\
\text { hipoglikemik }\end{array}$ & 3 \\
\hline 4. & P & $\begin{array}{l}\text { Diberikan ekstrak tempe kedelai hitam dan ubi jalar } \\
\text { ungu dengan rasio 1:1 secara oral (gavage) sebanyak } \\
\text { 1 ml/ekor/hari selama 28 hari }\end{array}$ \\
\hline
\end{tabular}

Pengumpulan data. Data penelitian berupa berat badan, kadar glukosa darah, tingkat kerusakan membran sel, dan hematokrit darah.

1. Kadar glukosa darah. Pengukuran kadar glukosa darah dilakukan dengan menggunakan dari yang berasal dari ujung ekor. Pengenceran dilakukan dengan menggunakan alat strip Blood Glucose Test Meter dan ditunggu 10 detik sehingga terbaca dengan satuan $\mathrm{mg} / \mathrm{dl}$.

2. Berat badan. Penimbangan berat badan tikus perlakuan.

3. Tingkat kerusakan membran eritrosit. Darah dilarutkan dalam larutan $\mathrm{NaCl}$ $0,7 \%, 0,9 \%$ dan $1 \%$. Laju kerusakan membran eritrosit diamati di bawah mikroskop, dicatat perubahan bentuk sel (krenasi dan hemolisis). Pengamatan dilakukan sebanyak 4 kali dalam satu bidang pandang (setelah 10 menit melarutkan darah dalam larutan $\mathrm{NaCl}$ ).

4. Hematokrit. Nilai hematokrit ditentukan dengan menggunakan metode pembanding antara jumlah plasma dengan eritrosit yaitu dengan memasukkan 2/3 darah ke dalam tabung eppendorf, selanjutnya dilakukan sentrifugasi dengan mikrosentrifus (10 menit, kecepatan 3000 rpm). Hasil sentrifugasi didokumentasikan sebelum plasma dan ertrosit diambil dengan mikropipet (ukuran mL).

Analisis data. Teknik analisis data yang digunakan dalam penelitian adalah analisis deskriptif dan perbandingan foto, yaitu membuat deskripsi, gambaran sistematis, faktual dan akurat mengenai fakta-fakta serta hubungan antar fenomena campuran kedelai hitam dan ubi jalar ungu dengan toleransi osmotik.

\section{HASIL}

Hasil penelitian berupa rerata kadar glukosa darah dan berat badan yang diukur awal, setelah pemberian HFD dan setelah perlakuan pemberian campuran ekstrak tempe kedelai hitam dan ubi jalar ungu. Rerata kadar glukosa darah pada Tabel 2 dan rerata berat badan dapat dilihat pada Tabel 3 .

Tabel 2. Rerata kadar glukosa darah tikus

\begin{tabular}{cccc}
\hline & \multicolumn{3}{c}{ Rerata Kadar Glukosa Darah (mg/d) } \\
\cline { 2 - 4 } & $\begin{array}{c}\text { Awal } \\
\text { (Sebelum HFD) }\end{array}$ & $\begin{array}{c}\text { Setelah HFD } \\
\text { (Sebelum perlakuan) }\end{array}$ & Setelah Perlakuan \\
\hline $\mathbf{N}$ & 82 & 103 & 124 \\
\hline $\mathbf{K}-$ & 79 & 210 & 376 \\
\hline $\mathbf{K}+$ & 101 & 250 & 109 \\
\hline $\mathbf{P}$ & 51 & 453 & 210 \\
\hline
\end{tabular}

Tabel 3. Rerata berat badan tikus

Awal

(Sebelum HFD)

\section{Rerata Berat badan (g)}

Setelah HFD

(Sebelum perlakuan)
Setelah Perlakuan 


\begin{tabular}{cccc}
\hline $\mathbf{N}$ & 94 & 169 & 184 \\
\hline $\mathbf{K}-$ & 100 & 176 & 156 \\
\hline $\mathbf{K}+$ & 98 & 185 & 173 \\
\hline $\mathbf{P}$ & 98 & 166 & 200 \\
\hline
\end{tabular}

Gambar 1. menunjukkan nilai hematokrit tikus normal $46 \%$ dan tikus model DMT2 tanpa perlakuan $61 \%$. Tikus model DMT2 diberi perlakuan obat glibenclamid memiliki nilai lebih rendah $(51 \%)$ dibandingkan dengan tikus model DMT2 yang di berikan senyawa alami ekstrak tempe kedelai hitam dan ubi jala ungu (59\%). Sedangkan Gambar 2 menunjukkan toleransi osmotik pada tingkat kerusakan membran eritrosit.

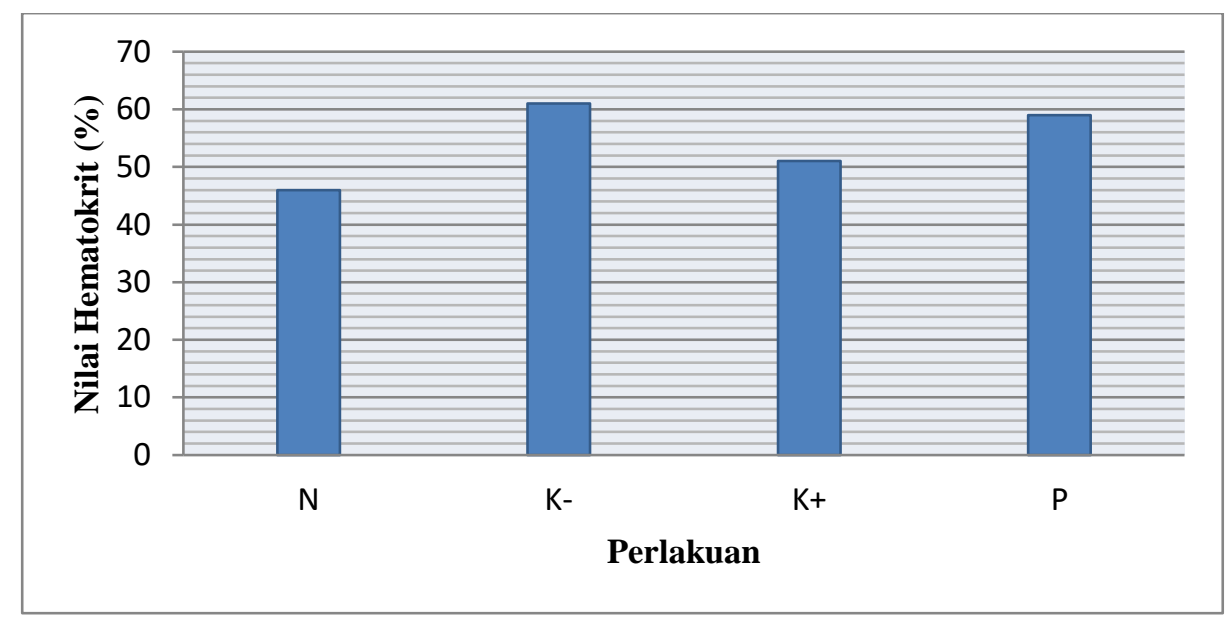

Gambar 1. Nilai hematokrit tikus DMT2

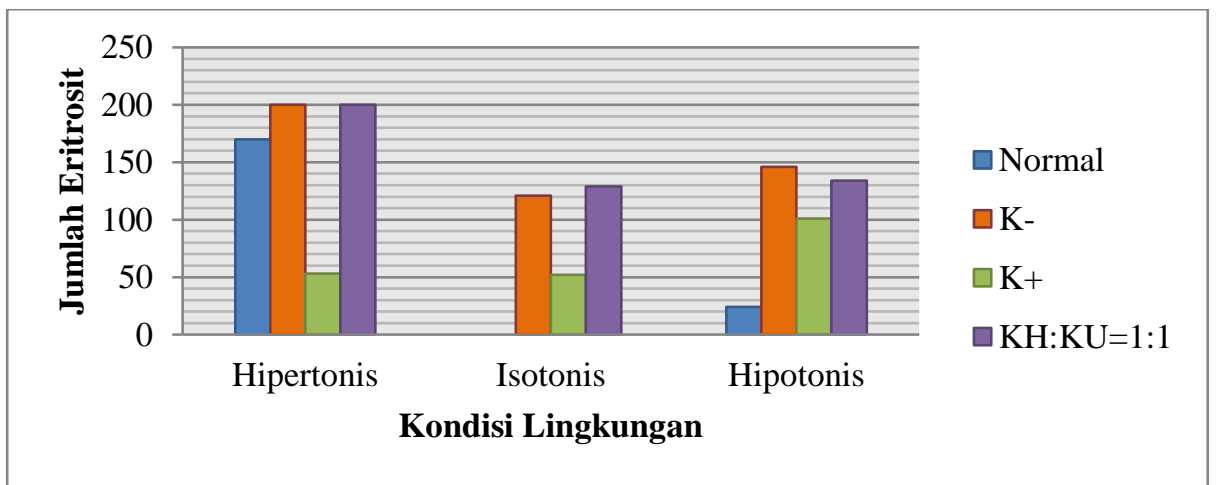

Gambar 2. Toleransi osmotik eritrosit pada berbagai kepekatan medium

\section{PEMBAHASAN}

Tabel 2 menunjukkan bahwa penggunaan kombinasi ekstrak tempe kedelai hitam dan ubi jalar ungu dapat menurunkan kadar glukosa darah, hal ini menunjukkan perbaikan kemampuan sel $\beta$ dalam mensekresikan insulin sehingga insulin dapat digunakan untuk melepaskan glukosa dari hati ke dalam sel dan kemudian disimpan dalam bentuk glikogen dan dikeluarkan menjadi energi. Penurunan kadar glukosa darah puasa juga menunjukkan penurunan produksi glukosa di hati (Stapley, 2001; Tirosh et al., 2011).
Kombinasi ekstrak tempe kedelai hitam dan ubi jalar ungu mengandung berbagai antioksidan terutama golongan flavonoid. Konsumsi senyawa flavonoid dapat mengurangi radikal hidroksil dan radikal peroksil (Chu et al., 2000; Ou et al., 2002), namun jenis senyawa yang berpengaruh dan mekanisme hipoglikemik kombinasi ekstrak belum diketahui.

Rerata berat badan tikus model DMT2 pada tabel 3 menunjukkan hasil bahwa penggunaan kombinasi ekstrak memiliki efek lebih baik dengan obat glibenklamid. Menurut 
Wijaya $d k k$. (2015) dan Putra $d k k$. (2017) pengobatan yang biasa diberikan pada penderita DM bertujuan untuk mengendalikan kadar glukosa darah agar selalu berada dalam kondisi normal. Pemberian obat antidiabetik oral (glibenclamid, metformin, dll) dapat menurunkan kadar glukosa darah penderita DMT2.

Hasil penelitian yang ditunjukkan pada gambar 1 menjelaskan bahwa nilai hematokrit darah tikus kelompok $\mathrm{N}$ dan $\mathrm{K}+$ berada pada ambang batas normal (39-53\%) (Aboderin and Oyetayo, 2006). Tikus DMT2 yang di beri perlakuan obat glibenclamid memberi efek positif terhadap penurunan nilai hematokrit, sedangkan peningkatan hematokrit akan berpengaruh terhadap dehidrasi di jaringan. DMT2 berhubungan dengan peningkatan kadar glukosa darah. Kadar glukosa akan meningkat setelah makan menyebabkan keluarnya air dari jaringan. Dehidrasi di jaringan terjadi akibat efek osmotik glukosa. Jaringan yang mengalami dehidrasi fungsinya akan terganggu (Fathurohman dan Fadhilah, 2016).

Toleransi osmotik darah dapat diukur menggunakan parameter tingkat kerusakan membran eritrosit. Tikus sebagai hewan coba memiliki cairan tubuh isotonis dengan $0,9 \%$ $\mathrm{NaCl}$ sehingga tidak terjadi kerusakan membran eritrosit. Hal ini sesuai dengan pernyataan Soewolo (2000) bahwa tikus normal isotonis pada larutan $\mathrm{NaCl} 0,9 \%$ dan mengalami kerusakan membran eritrosit akibat adanya perubahan lingkungan hipertonis dan hipotonis. Tikus DMT2 pada kondisi isotonis, hipertonis dan hipotonis memiliki toleransi osmotik yang rendah ditunjukkan dengan tingkat kerusakan membran eritrosit dibandingkan dengan tikus normal, hal ini sesuai dengan penelitian Kung et al. (2009) yang menjelaskan bahwa toleransi osmotik rendah pada DMT2 dibandingkan dengan kontrol non diabetes.

Dari hasil penelitian toleransi osmotik pada gambar 2 menunjukkan bahwa campuran ekstrak tempe kedelai hitam dan ubi jalar ungu mempunyai senyawa alami berupa flavonoid. Flavonoid dapat memodulasi metabolisme lipid, glukosa abnormal, memperbaiki resistensi insulin perifer, mengurangi komplikasi diabetes yang disebabkan oleh abnormalitas profil lipid dan resistensi insulin, menghindari absorpsi glukosa atau memperbaiki toleransi glukosa, mengatur aktivitas dan ekspresi enzim yang terlibat dalam jalur metabolism karbohidrat serta bertindak menyerupai insulin dengan mempengaruhi mekanisme insulin signaling (Zhao et al., 2006; Cazarolli et al., 2008).

\section{KESIMPULAN}

Toleransi osmotik eritrosit tikus ditunjukkan dengan perubahan bentuk sel eritrosit pada lingkungan hipotonis, isotonis dan hipertonis. Kelompok perlakuan pemberian senyawa kimia berupa obat glibenklamid bekerja lebih baik menurunkan kerusakan membran sel dibandingkan dengan pemberian senyawa alami campuran ekstrak tempe kedelai hitam dan ubi jalar ungu diduga karena senyawa kimia pada obat bekerja lebih cepat dalam menormalkan toleransi osmotik pada DMT2.

\section{UCAPAN TERIMAKASIH}

Penulis mengucapkan terima kasih kepada Ibu Dr. Sri Rahayu Lestari, Dr. Abdul Gofur, M.Si, laboran di Lab. Fisiologi Hewan, dan rekan-rekan proyek penelitian yang telah membantu hingga selesainya penelitian ini. Penelitian ini adalah payung penelitian dari Dr. Abdul Gofur, M.Si, $d k k$ dengan nomor kontrak 3.4.8/ UN32.14/LT/2017.

\section{DAFTAR PUSTAKA}

Aboderin FI and Oyetayo VO. 2006. Haematological Studies of Rats Fed Different Doses of Probiotic, Lactobacillus plantarum, Isolated from Fermenting Corn Slurry. Pakistan Journal of Nutrition. vol 5(2): 102-105. https://doi.org/10.3923/pjn.2006.102.105. Ahmed N. 2005. Advanced Glycation Endproducts-Role in Pathology of Diabetic Complications. Diabetes Res Clin Pract. vol 67(1): 3-21. https://doi.org/10.1016/j.diabres.2004.09. $\underline{004}$. 
American Diabetes Association. 2014. Standards of Medical Care in Diabetes. Diabetes Care. Suppl 1:S14-80. https://doi.org/10.2337/dc14-S014.

Arjadi F dan Mustofa. 2017. Ektrak Daging Buah Mahkota Dewa Meregenerasi Sel Pulau Langerhans Pada Tikus Putih Diabetes. Biogenesis. vol 5(1): 27-33. https://doi.org/10.24252/bio.v5i1.3430.

Betteng R, Pangemanan D, Mayulu N. 2014. Analisis Faktor Resiko Penyebab Terjadinya Diabetes Mellitus Tipe 2 pada Wanita Usia Produktif di Puskesmas Wawonasa. Jurnal e-Biomedik. vol 2(2): 404-412.

Cazarolli LH, Zanatta L, Alberton EH, Figueiredo MS, Folador P, Damazio RG, Pizzolatti MG, Silva FR. 2008. Flavonoids: Cellular and Molecular Mechanism of Action in Glucose Homeostasis. Mini Rev Med Chem. vol 8(10): 1032-1038.

Cheng KC, Lin JT, Liu WH. 2011. Extract from Fermented Black Soybean Milk Exhibit Antioxidant and Cytotoxic Activities. Food Technology and Biotechnology. vol 49(1): 111-117.

Chu YH, Chang CL, Hsu HF. 2000. Flavonoid Content of Several Vegetables and Their Antioxidant Activity. Journal of the Science of Food and Agriculture. Vol 80(5):

561-566.

https://doi.org/10.1002/(SICI)10970010(200004)80:5<561::AID-

JSFA574>3.0.CO;2-\#.

Fathurohman I dan Fadhilah M. 2016. Gambaran Tingkat Risiko dan Faktorfaktor yang Berhubungan dengan Risiko Diabetes Mellitus Tipe 2 di Buaran, Serpong. Jurnal Kedokteran Yarsi. vol 24 (3) : 186-202.

Franz MH, Boucher JL, Evert AB. 2014. Evidence-Based Diabetes Nutrition Therapy Recommendations are Effective: The Key is Individualization. Diabetes Metab Syndr Obes. vol 7: 6572. https://doi.org/10.2147/DMSO.S451 $\underline{40}$.

Hakim BH, Abdullah AZ, Hanis M. 2009. Analisis Faktor Risiko Diabetes Melitus tipe 2 di Puskesmas Tanrutedong, Sidenreng Rappang. MEDIKA: Jurnal Kedokteran Indonesia. vol 35(4): 228.

Johnson DR, Sherry CL, York JM, Freund GG. 2008. Acute Hypoxia, Diabetes, and Neuroimmune Dysregulation: Converging Mechanisms in the Brain. Neuroscientist. vol 14(3): 235-239. https://doi.org/10.1177/10738584073095 44.

Kung CM, Tseng ZL, Wang HL. 2009. Erythrocyte Fragility Increases With Level of Glycosylated Hemoglobin in Type 2 Diabetic Patients. Clin Hemorheol Microcirc. vol 43(4): 345-351. https://doi.org/10.3233/CH-2009-1245.

Lippi G, Mercadanti M, Aloe R, Targher G. 2012. Erythrocyte Mechanical Fragility is increased in Patients with Type 2 Diabetes. Eur J Intern Med. vol 23(2): 150-153.

https://doi.org/10.1016/j.ejim.2011.11.00 $\underline{4}$.

Montilla EC, Hillebrand S, Winterhalter P. 2011. Anthocyanins in Purple Sweet Potato (Ipomoea batatas L.) Varieties. Fruit, Vegetable, and Cereal Science and Biotechnology. vol 5(2): 19-24.

$\mathrm{Ou}$ B, Huang D, Hampsch-Woodill M, Flanagan JA, Deemer EK. 2002. Analysis of Antioxidant Activities of Common Vegetables Employing Oxygen Radical Absorbance Capacity (ORAC) and Ferric Reducing Antioxidant Power (FRAP) Assays: A Comparative Study. J. Agric. Food Chem. vol 50(11): 3122-3128. https://doi.org/10.1021/jf0116606.

Putra RJS, Achmad A, P HR. 2017. Kejadian Efek Samping Potensial Terapi Obat Anti Diabetes Pasien Diabetes Melitus Berdasarkan Algoritma Naranjo. Pharmaceutical Journal of Indonesia. vol 2(2): 45-50.

Prabhu S. 2013. Genetic and Biochemical Risk Factors for Type 2 Diabetes Mellitus. Indian Journal of Biotechnology. vol 12(4): 447-450.

Rimbawan dan Siagian A. 2004. Indeks Glikemik Pangan. Jakarta: Penebar Swadaya. hal 57-80. 
Silverthorn DU. 2002. Fisiologi Manusia: Sebuah Pendekatan Terintegrasi. Edisi 6. Jakarta: Penerbit EGC.

Singh M and Shin S. 2009. Changes in Erythrocyte Aggregation and Deformability in Diabetes mellitus: A Brief Review. Indian J Exp Biol. vol 4(1): 7-15.

Soewolo. 2000. Pengantar Fisiologi Hewan. Jakarta: Dirjen Dikti Depdiknas. hal. 250.

Stapley L. 2001. The History of Diabetes Mellitus. Trends in Endocrinology \& Metabolism. vol 12(6): 277. https://doi.org/10.1016/S10432760(01)00453-2.

Tamariz LJ, Young JH, Pankow JS, Yeh HC, Schmidt MI, Astor B, Brancati FL. 2008. Blood Viscosity and Hematocrit as Risk Factors for Type 2 Diabetes Mellitus: The Atherosclerosis Risk in Communities (ARIC) Study. Am J Epidemiol. https://doi.org/10.1093/aje/kw $\underline{\mathrm{n} 243}$.
Tirosh A, Shail I, Afek A, Dubnov-Raz G, Ayalon N, Gordon B, Derazne E, Tzur D, Shamis A, Vinker S, Rudich A. 2011. Adolescent BMI Trajectory and Risk of Diabetes versus Coronary Disease. $N$ Engl J Med. vol 364:1315-1325. https://doi.org/10.1056/NEJMoa1006992.

Wijaya IN, Faturrohmah A, Yuda A, Mufarrihah, Soesanto TG, Kartika D, Agustin WW, Putri HPNS. 2015. Profil Penggunaan Obat Pada Pasien Diabetes Melitus di Puskesmas Wilayah Surabaya Timur. Jurnal Farmasi Komunitas. vol 2(1): 23-28.

Zhao R, Li Q, Long L, Li J, Yang R, Gao D. 2006. Antidiabetic Activity of Flavone from Ipomoea batatas Leaf in NonInsulin Dependent Diabetic Rats. Int $J$ Food Sci Tech. vol 42(1): 80-85. https://doi.org/10.1111/j.13652621.2006.01215.x. 